\title{
EDITORIAL
}

\section{THE ROLE OF TERMINOLOGY IN THE CONTEMPORARY SECURITY ENVIRONMENT}

This year's first issue of the Contemporary Military Challenges is dedicated to military terminology. In over twenty years of the journal, we have not yet published a thematic issue specifically addressing this field, although throughout the years of its development, questions, dilemmas, and debates about the individual terms, concepts, and translations, and their true meaning have always been present. This does not mean, however, that nobody in the defence sector has dealt with this area. Quite the contrary; from the articles, our readers will be able to learn about the history, organization, development, opportunities and challenges faced by terminologists, proofreaders, translators, editors and, last but not least, all other stakeholders, not only from the field of defence, but also from the broader Slovenian environment.

The authors of the articles in this issue often refer to the historical context in which the Slovene language has evolved, putting an emphasis on the military profession. In this respect, it is important to note that Slovene military language has a rich history. On this occasion it is also worth mentioning the Slovenian nobleman and military Major, Andrej Komel Sočebran, the founder of Slovene military language. Among other things, he also endeavoured to translate various German military terms into Slovene. He published two books, Osnova vojstva (Basis of the Military in 1884, and Organizacija vojstva (Organization of the Military in 1890. The Slovene term "vojstvo" as the equivalent of "the military", however, is no longer used in today's technical security-, defence- and military-related language. In 1996, the Ministry of Defence began to publish the journal entitled "Vojstvo", but only until the year 2000. On page 3 of the introduction to the first issue of the publication, Dr Tomo Korošec, a professor and expert in military terminology, explained the reasons for choosing the word "vojstvo" as its title. He argued that with the word "vojstvo", Komel had found an excellent translation of the German term for the military as an overarching term covering soldiers, war and everything related to the military and defence. In Slovene, all these words, including their adjectival derivatives, are derived from the 
same root $v o j$ - combined with different suffixes, such as - $a k$ (soldier), -na (war), -ska (army), and -aštvo (military).

Unfortunately, neither the term "vojstvo" nor the publication with that title have been preserved. The number and variety of military terminology challenges have been significantly influenced by the integration of the Republic of Slovenia into the international security environment, as well as by the desire and the need to synchronize military technical terminology to ensure better organization and the effectiveness of joint efforts.

In the article Contemporary trends in Slovene military terminology by Tina Pečovnik, we learn about the procedures, criteria and laws in establishing standards and interaction with other terminologists and institutions in Slovenia. The author provides a typological classification of some of the most recent Slovene military terms and emphasizes the need for a more systematic collection and study of terminology. In this regard, she points out some of the demanding Slovene terminological choices for different concepts.

Tamara Derman Zadravec focused on the Standardization of Slovene military terminology. In her article, she explains in detail what the term standardization means, how standardization takes place and why it is needed in the Slovenian environment. She explains the reasons why it plays such an important role both within the Alliance and in the cooperation between NATO member states. Finally, she presents the guidelines for the future development of Slovene military terminology.

In the article Terminology management in Slovenian military environment and examples of good practice, Ana Hazler explains in detail how translators and terminologists in the Slovenian defence system and the Slovenian Armed Forces worked and continue to work. She specifically presents proposals for future efforts based on the findings obtained through a comparative analysis of the practices of other NATO member states in the area of military terminology development.

Un-/justified terminological intervention in the use of Slovene equivalents for the term aircraft is the title of an article by Vanesa Škornik. She presents various aspects and dimensions of the challenges faced by linguists, proofreaders, translators and other subject-matter experts in the fields of security, defence and the military, as well as by others, such as air personnel or sailors. Which term is the right one to choose considering the usage, and how to justify it? More about this in the article.

In his article Standardization and terminology in NATO - the role of Centres of Excellence Rafael Kolbl writes about standardization in NATO, which is important for Slovenia's cooperation with other Allies. The NATO Mountain Warfare Centre of Excellence in the Republic of Slovenia also faces various challenges in the field of military terminology. The author presents variations in the understanding of the concept of mountains, whose altitude (hills, knolls, etc.) varies according to different 
countries and regions in geographical terms, which consequently calls for a different approach to warfare.

A case study of how to translate and, consequently, adequately define certain concepts, was prepared by Nina Raduha and Iris Žnidarič in the article Terminology as the cornerstone of the defence and military profession - the case of NATO's Strategic Communications Concept. Often, translation alone does not provide an adequate term in a certain subject-matter field, which means that an appropriate term still has to be found. When such a term already exists and means something else similar in some other subject-matter area, the challenge becomes all the more interesting.

In the article Impact of artificial intelligence development on national security, Mojca Pešec explains the terminology and definition of artificial intelligence, what this concept encompasses and where it appears in the field of security. There are many definitions and forms in many fields. Some of them are of particular interest to the security and defence systems and armed forces, which will in the future require additional attention dedicated to artificial intelligence terminology and systems in the field of defence and security.

What does the term strategy mean and what are the differences in its use within different scientific and research fields? What does the term military strategy mean and how does it differ from political strategy? Is it a theory or practice of strategy? The importance of strategies in history, their importance today, and what will happen with this term in the future, was explored by Pavel Vuk in his article Challenges to military strategy in the 21 st century.

The number of female authors in this issue is far larger than the number of male authors. The year 2020 marks the 20th anniversary of the adoption of the United Nations Security Council Resolution 1325, which is dedicated to women, peace and security. The ratio between female and male authors in this issue is purely coincidental and has nothing to do with this anniversary; however, is it possible that the field of terminology is perhaps still more appealing to women, especially profession-wise? 